\title{
DENSITAS MASSA TULANG PADA PENGGUNA KONTRASEPSI IMPLAN LEVONORGESTREL
}

\author{
Andriana Kumala Dewi ${ }^{1}$, Djaswadi Dasuki ${ }^{2}$, Diah Rumekti Hadiati ${ }^{3}$
}

\begin{abstract}
Background: BKKBN reported that implant as a long term method of contraception was the most widely used among new users in 2012. The contraceptive action is mainly by inhibition of ovulation and production of estrogen is supressed. Estrogen is one of the most important factors related to bone remodelling. Thus, it has raised concerns regarding the adverse effect of long term use of this contraceptive method on the bone status of women who use them. So, it is necessary to study the effects of long term use of progestogens on bone mineral density.

Objective: Comparing bone mass density in contraceptive implant users and non-hormonal users.

Methods: Cross sectional study. This study was conducted in Kontap, outpatient department, Sardjito Hospital in August-December 2013. The participants' age were $20-50$ years who met the inclusion criteria and regardless of the exclusion criteria. Total of 110 women were divided into 2 groups, contraceptive implant users and nonhormonal contraceptive users. Bone mass density was measured using ultrasound densitometry on the calcaneus bone.

Results: Bivariate Chi-square analysis showed that there was no significant association between the use of the contraceptive implant with incidence of abnormal bone density (RP $1.75 ; 95 \% \mathrm{Cl}(0.80-3.83), \mathrm{p}=0.23$ ). BMI as confounding variable provide a significant relationship with bone density with $\mathrm{OR} 23.24 ; 95 \% \mathrm{Cl}$ (4.26 to 126.86$)$, $\mathrm{p}<0.001$

Conclusion: In this study, there was no significant difference of bone mass density between contraceptive implant group and non hormonal group. BMI were significantly related to bone mass density.
\end{abstract}

Keyword: Bone mineral density, contraceptive implant, contraceptive progestin-only, levonorgestrel

\begin{abstract}
ABSTRAK
Latar belakang: Data BKKBN menunjukkan bahwa implan merupakan metode kontrasepsi jangka panjang terbanyak dipakai oleh peserta baru KB tahun 2012. Cara kerja utama implan levonorgestrel dengan inhibisi ovulasi sehingga terjadi supresi produksi estrogen. Estrogen adalah salah satu faktor penting dalam remodelling tulang. Hal inilah yang memunculkan kekhawatiran tentang pengaruh penggunaan implan terhadap status kesehatan tulang pemakainya.

Tujuan: Membandingkan densitas massa tulang pada pengguna kontrasepsi implan levonorgetrel dan non hormonal.

Metode penelitian: Studi potong lintang. Penelitian dilakukan di Poliklinik Kontap, RSUP Dr. Sardjito. Jumlah peserta penelitian 110 wanita berusia 20-50 tahun yang memenuhi kriteria inklusi dan terlepas dari kriteria eksklusi, terbagi menjadi 2 kelompok, yaitu kelompok pengguna kontrasepsi implan dan pengguna kontrasepsi non hormonal. Densitas massa tulang diukur dengan menggunakan alat densitometri ultrasonografi pada tulang kalkaneus.

Hasil: Analisis bivariat Chi-square menunjukkan bahwa tidak ada hubungan bermakna antara penggunaan kontrasepsi implan dengan kejadian densitas tulang yang tidak normal (RP 1,75; IK 95\% $(0,80-3,83), p=0,23)$. BMI
\end{abstract}

\footnotetext{
* Bagian Obstetri dan Ginekologi FK UGM/RSUP Dr. Sardjito Yogyakarta
} 
sebagai variabel luar memberikan hasil analisis yang bermakna terhadap kejadian densitas tulang tidak normal dengan nilai OR 23,24; IK 95\% (4,26-126,86), p<0,001.

Kesimpulan: Tidak ada perbedaan densitas massa tulang yang bermakna antara kelompok pengguna kontrasepsi implan dan non hormonal. BMI kategori underweight secara signifikan memiliki hubungan dengan kejadian densitas tulang tidak normal.

Kata kunci: densitas massa tulang, kontrasepsi implan, kontrasepsi progestin-only, levonorgestrel

\section{PENDAHULUAN}

Menurut data statistik dari Badan Koordinasi Keluarga Berencana Nasional, implan merupakan metode kontrasepsi jangka panjang terbanyak dipakai oleh peserta baru KB pada bulan Januari-Desember 2012, disusul alat kontrasepsi dalam rahim (AKDR). ${ }^{1}$

Salah satu golongan utama dari kontrasepsi progestin-only adalah turunan testosteron yaitu levonorgestrel. Implan levonorgestrel mencegah terjadinya kehamilan melalui mekanisme kerja antara lain mencegah terjadinya ovulasi dengan menekan hipotalamus serta Luteinizing Hormon (LH) surge, dan juga menyebabkan hipoplasi endometrium sehingga menurunkan keberhasilan implantasi. ${ }^{2,3}$

Pengaruh kontrasepsi golongan progestin-only terhadap densitas tulang sampai saat ini masih kontroversial. Penggunaan beberapa golongan kontrasepsi progestin-only mempengaruhi tingkat serum estrogen terutama pada wanita yang mengalami amenorea. ${ }^{4}$ Estrogen merupakan prevensi penting dalam mempertahankan kadar densitas tulang. Pengaruh positif estrogen terhadap densitas tulang ialah dengan menghambat aktifitas osteoclasts yang menyebabkan proses resorbsi tulang. ${ }^{5}$

Data yang diperoleh dari penelitian ini diharapkan memberikan informasi yang bermanfaat tentang keamanan pemakaian implan terhadap densitas tulang, dimana densitas tulang yang rendah merupakan faktor risiko terjadinya fraktur di masa pasca menopause. Sedangkan angka penggunaan kontrasepsi ini cukup tinggi diantara kalangan akseptor KB.

\section{BAHAN DAN CARA KERJA}

Penelitian ini merupakan studi potong lintang dan dilaksanakan di Poliklinik Kontap, RSUP dr. Sardjito Yogyakarta, bulan Agustus-Desember 2013. Penghitungan besar sampel berdasarkan penelitian sebelumnya yaitu Pongsatha et $a l .{ }^{6}$ Penelitian ini menggunakan $Z_{1-\hat{a}}=1,96$ dan $Z_{1-\hat{a}}=0,84$. Besar prevalensi kontrasepsi implan dan non hormonal dengan densitas tulang tidak normal adalah $20 \%$ dan $4 \%$. Total peserta penelitian 110 wanita terbagi 2 yaitu kelompok pengguna kontrasepsi implan dan non hormonal. Kriteria inklusi adalah wanita berusia 2050 tahun, menggunakan kontrasepsi implan dan non hormonal minimal 2 tahun, tidak sedang menyusui. Kriteria eksklusi adalah subyekyang memiliki penyakit kronis seperti: DM, gagal ginjal kronis, hiper/hipotiroidsm, hiper/hipoparatiroidsm, hepatitis, penyakit keganasan, penyakit pituitari, penyakit sendi, sedang menggunakan obat-obatan seperti heparin, antikonvulsan, tiroksin, kortikosteroid maupun suplemen yang dapat mempengaruhi metabolisme tulang, perokok dan peminum alkohol. Pengukuran densitas massa tulang dilakukan dengan alat densitometri ultrasound portable pada tulang kalkaneus. Hasil pengukuran dilaporkan dalam bentuk T-score, yaitu standar deviasi antara masa tulang individu yang dilakukan pemeriksaan dengan puncak masa tulang rata-rata dewasa muda.

\section{HASIL DAN PEMBAHASAN}

Karakteristik subyek penelitian dapat dilihat pada tabel 1. Mayoritas peserta berusia kurang dari 35 tahun (56,4\%). Paritas $£ 3$ pada peserta sebesar $89,1 \%$. Lama pemakaian kontrasepsi mayoritas 
adalah $>5$ tahun yaitu $43,6 \%$. Riwayat pemakaian KB hormonal sebelumnya $34,5 \%$ dan non hormonal sebanyak $65,5 \%$. Kelompok BMI $<18,5$ sebanyak $12,7 \%$. Mayoritas peserta mengalami menarchesaat berusia kurang dari 15 tahun yaitu sebesar $71,8 \%$.

Tabel 1. Karakteristik sampel penelitian

\begin{tabular}{|c|c|c|}
\hline Karakteristik & $\begin{array}{c}\text { Jumlah } \\
\text { (n) }\end{array}$ & $\begin{array}{c}\text { Persentase } \\
(\%)\end{array}$ \\
\hline \multicolumn{3}{|l|}{ Jenis kontrasepsi } \\
\hline Implan & 55 & 50 \\
\hline Non hormonal & 55 & 50 \\
\hline \multicolumn{3}{|l|}{ Umur } \\
\hline$\geq 35$ tahun & 48 & 43,6 \\
\hline$<35$ tahun & 62 & 56,4 \\
\hline \multicolumn{3}{|l|}{ Paritas } \\
\hline$>3$ & 12 & 10,9 \\
\hline$\leq 3$ & 98 & 89,1 \\
\hline \multicolumn{3}{|l|}{ Lama pemakaian } \\
\hline$\geq 5$ tahun & 48 & 43,6 \\
\hline $3-<5$ tahun & 41 & 37,3 \\
\hline$<3$ tahun & 21 & 19,1 \\
\hline \multicolumn{3}{|l|}{ Riwayat } \\
\hline \multicolumn{3}{|l|}{ kontrasepsi } \\
\hline KB hormonal & 38 & 34,5 \\
\hline Non hormonal & 72 & 65,5 \\
\hline \multicolumn{3}{|l|}{ BMI } \\
\hline$<18,5$ & 14 & 12,7 \\
\hline $18,5-<25$ & 67 & 60,9 \\
\hline$\geq 25$ & 29 & 26,4 \\
\hline \multicolumn{3}{|l|}{ Menarche } \\
\hline$\geq 15$ tahun & 31 & 28,2 \\
\hline$<15$ tahun & 79 & 71,8 \\
\hline
\end{tabular}

Hubungan antara jenis kontrasepsi dan densitas tulang dapat dilihat dengan analisis bivariat Chi-
Square pada tabel 2. Hasil analisis menunjukkan tidak ada perbedaan densitas massa tulang yang bermakna pada kelompok pengguna kontrasepsi implan dan kelompok pengguna kontrasepsi non hormonal dengan RP 1,75, IK 95\% (0,80-3,83), $p=0,23$.

Pada tabel 3 dapat dilihat bahwa hanya BMI memiliki hubungan yang bermakna dengan densitas tulang. Peserta yang mempunyai $\mathrm{BMI}<18,5$ dan $\mathrm{BMI}$ 18,5-<25 memiliki masing-masing RP 6,91; IK 95\% $(2,25-21,19)$ dan RP 5,32; IK 95\% (2,66-10,63) dengan nilai $p=0,001$. Sedangkan umur (RP 0,60; IK 95\% (0,27-1,36), $p=0,31$ ), paritas (RP 1,82; IK 95\% $(0,74-4,48), p=0,25)$, lama pemakaian kontrasepsi (RP 0,51; IK 95\% $(0,19-1,34), p=0,30)$, riwayat kontrasepsi sebelumnya (RP 0,56; IK 95\% (0,221,39), $p=0,29$ ) dan usia menarche (RP 1,19; IK 95\% $(0,54-2,63), p=0,87)$ tidak memiliki hubungan bermakna dengan densitas tulang.

Tabel 4 menunjukkan bahwa lama pemakaian kontrasepsi memiliki hubungan bermakna dengan jenis kontrasepsi yang dipakai oleh peserta penelitian. Pada lama pemakaian kontrasepsi $\geq 5$ tahun didapatkan RP 2,53; IK 95\% (0,99-6,37), $p=0.045$ dan pemakaian 3-<5 tahun didapat RP 3,59; IK 95\% $(1,45-8,87)$ dan nilai $p=0,001$. Sedangkan umur (RP 1,34; IK 95\% (0,93-1,94), $p=0,18)$, paritas (RP 1,60; IK $95 \%(0,98-2,63), p=0,06)$, riwayat kontrasepsi sebelumnya (RP 1,00; IK 95\% (0,68-1,48), $p=1,00)$ dan usia menarche (RP 0,96; IK 95\% (0,63-1,46), $p=1,00)$ tidak mempunyai hubungan bermakna dengan jenis kontrasepsi karena nilai $p>0,05$.

Tabel 2. Analisis bivariat hubungan antara variabel bebas (jenis kontrasepsi) dan variabel tergantung (densitas massa tulang)

\begin{tabular}{|c|c|c|c|c|c|c|c|c|}
\hline \multirow{2}{*}{$\begin{array}{l}\text { Jenis } \\
\text { kontrasepsi }\end{array}$} & \multicolumn{2}{|c|}{$\begin{array}{c}\text { DMT tidak } \\
\text { normal }\end{array}$} & \multicolumn{2}{|c|}{$\begin{array}{c}\text { DMT } \\
\text { normal }\end{array}$} & \multirow[t]{2}{*}{$\mathbf{R P}$} & \multirow[t]{2}{*}{$\mathbf{P}$} & \multicolumn{2}{|c|}{ IK 95\% } \\
\hline & $\mathrm{n}$ & $\%$ & $N$ & $\%$ & & & & \\
\hline Implan & 14 & 25,5 & 41 & 74,5 & 1,75 & 0,23 & $(0,80$ & $-3,83)$ \\
\hline Non & 8 & 14,5 & 47 & 85,5 & & & & \\
\hline Hormonal & & & & & & & & \\
\hline
\end{tabular}


Hasil analisis multivariat dapat dilihat pada tabel 5. Model 1 bertujuan untuk melihat hubungan penggunaan jenis kontrasepsi dengan densitas tulang tanpa disertai pengaruh lain. Setelah dilakukan pengujian didapatkan hasil tidak ada hubungan bermakna antara pemakaian kontrasepsi implan dengan kejadian densitas tulang tidak normal dengan OR 2,01; IK 95\% $(0,77-5,26), p=0,16$. Model ini memberikan kontribusi sebesar $2 \%$ terhadap kejadian densitas tulang tidak normal.

Model 2 menggambarkan hubungan antara penggunaan jenis kontrasepsi dan densitas tulang dengan memasukkan variabel BMI. Hasil analisis menunjukkan perubahan nilai OR pada variabel kontrasepsi implan yaitu sebesar 2,14; IK $95 \%$ (0,706,52 ) namun secara statistik tidak bermakna karena nilai $\mathrm{p}=0,18$. Sedangkan BMI memiliki hubungan yang bermakna dengan densitas tulang dimana $\mathrm{BMI}<18,5$ OR 23,24; IK 95\% (4,26-126,86), $p=<0,001$. Dibandingkan dengan model 1 dapat dilihat bahwa dengan memasukkan variabel BMI terjadi peningkatan kontribusi kejadian densitas tulang tidak normal sebesar $19 \%$.

Tabel 3. Analisis bivariat hubungan antara variabel luar (umur, paritas, lama pemakaian kontrasepsi, riwayat kontrasepsi sebelumnya, BMI dan usia menarche) dan variabel tergantung (densitas massa tulang)

\begin{tabular}{|c|c|c|c|c|c|c|c|}
\hline \multirow[t]{2}{*}{ Variabel } & \multicolumn{2}{|c|}{$\begin{array}{c}\text { DMT tidak } \\
\text { normal }\end{array}$} & \multicolumn{2}{|c|}{$\begin{array}{c}\text { DMT } \\
\text { normal } \\
\end{array}$} & \multirow[t]{2}{*}{$\mathrm{RP}$} & \multirow[t]{2}{*}{$P$} & \multirow[t]{2}{*}{ IK 95\% } \\
\hline & $\mathrm{n}$ & $\%$ & $\mathrm{~N}$ & $\%$ & & & \\
\hline \multicolumn{8}{|l|}{ Umur } \\
\hline$\geq 35$ tahun & 7 & 14,6 & 41 & 85,4 & 0,60 & 0,31 & $(0,27-1,36)$ \\
\hline$<35$ tahun & 15 & 24,2 & 47 & 75,8 & & & \\
\hline \multicolumn{8}{|l|}{ Paritas } \\
\hline$>3$ & 4 & 33,3 & 8 & 66,7 & 1,82 & 0,25 & $(0,74-4,48)$ \\
\hline$\leq 3$ & 18 & 18,4 & 80 & 81,6 & & & \\
\hline \multicolumn{8}{|l|}{$\begin{array}{l}\text { Lama } \\
\text { pemakaian }\end{array}$} \\
\hline$\geq 5$ tahun & 7 & 14,6 & 41 & 85,4 & 0,51 & 0,30 & $(0,19-1,34)$ \\
\hline $3-<5$ tahun & 9 & 22 & 32 & 78 & 0,77 & 0,79 & $(0,32-1,87)$ \\
\hline$<3$ tahun & 6 & 28,6 & 15 & 71,4 & & & \\
\hline \multicolumn{8}{|l|}{$\begin{array}{l}\text { Riwayat } \\
\text { kontrasepsi }\end{array}$} \\
\hline Hormonal & 5 & 13,2 & 33 & 86,8 & 0,56 & 0,29 & $(0,22-1,39)$ \\
\hline $\begin{array}{l}\text { Non } \\
\text { Hormonal }\end{array}$ & 17 & 23,6 & 55 & 76,4 & & & \\
\hline \multicolumn{8}{|l|}{ BMI } \\
\hline$<18,5$ & 10 & 71,4 & 4 & 28,6 & 6,91 & $\begin{array}{l}0,001 \\
*\end{array}$ & $(2,25-21,19)$ \\
\hline $18,5-<25$ & 9 & 13,4 & 58 & 86,6 & 5,32 & $\begin{array}{l}0,001 \\
*\end{array}$ & $(2,66-10,63)$ \\
\hline$\geq 25$ & 3 & 10,3 & 26 & 89,7 & & & \\
\hline \multicolumn{8}{|l|}{ Menarche } \\
\hline$\geq 15$ tahun & 7 & 22,6 & 24 & 77,4 & 1,19 & 0,87 & $(0,54-2,63)$ \\
\hline$<15$ tahun & 15 & 19 & 64 & 81 & & & \\
\hline
\end{tabular}

* signifikan, nilai $\mathrm{p}<0,05$ 
Tabel 4. Analisis bivariat hubungan antara variabel bebas (jenis kontrasepsi) dan variabel luar (umur, paritas, lama pemakaian, riwayat kontrasepsi sebelumnya, BMI dan usia menarche)

\begin{tabular}{|c|c|c|c|c|c|c|c|}
\hline \multirow{2}{*}{ Variabel } & \multicolumn{2}{|c|}{ Implan } & \multicolumn{2}{|c|}{ Non Hormonal } & \multirow[t]{2}{*}{$\mathrm{RP}$} & \multirow[t]{2}{*}{$P$} & \multirow[t]{2}{*}{ IK 95\% } \\
\hline & $\mathrm{n}$ & $\%$ & $\mathrm{n}$ & $\%$ & & & \\
\hline \multicolumn{8}{|l|}{ Umur } \\
\hline$\geq 35$ tahun & 28 & 58,3 & 20 & 41,7 & 1,34 & 0,18 & $(0,93-1,94)$ \\
\hline$<35$ tahun & 27 & 43,5 & 35 & 56,5 & & & \\
\hline \multicolumn{8}{|l|}{ Paritas } \\
\hline$>3$ & 8 & 66,7 & 4 & 33,3 & 1,39 & 0,36 & $(0,87-2,18)$ \\
\hline$\leq 3$ & 47 & 48 & 51 & 52 & & & \\
\hline \multicolumn{8}{|c|}{ Lama pemakaian } \\
\hline$\geq 5$ tahun & 23 & 47,9 & 25 & 52,1 & 2,52 & $0,045^{*}$ & $(0,99-6,37)$ \\
\hline $3-<5$ tahun & 28 & 68,3 & 13 & 31,7 & 3,59 & $0,001 *$ & $(1,45-8,87)$ \\
\hline$<3$ tahun & 4 & 19 & 17 & 81 & & & \\
\hline \multicolumn{8}{|l|}{$\begin{array}{l}\text { Riwayat } \\
\text { kontrasepsi }\end{array}$} \\
\hline Hormonal & 19 & 50 & 19 & 50 & 1,00 & 1,00 & $(0,68-1,48)$ \\
\hline $\begin{array}{l}\text { Non } \\
\text { hormonal }\end{array}$ & 36 & 50 & 36 & 50 & & & \\
\hline \multicolumn{8}{|l|}{ BMI } \\
\hline$<18,5$ & 8 & 57,1 & 6 & 42,9 & 1,04 & 1,00 & $(0,59-1,81)$ \\
\hline $18,5-<25$ & 31 & 46,3 & 36 & 53,7 & 1,24 & 0,66 & $(0,73-2,08)$ \\
\hline$\geq 25$ & 16 & 55,2 & 13 & 44,8 & & & \\
\hline \multicolumn{8}{|l|}{ Menarche } \\
\hline$\geq 15$ tahun & 16 & 51,6 & 15 & 48,4 & 0,96 & 1,00 & $(0,63-1,46)$ \\
\hline$<15$ tahun & 39 & 49,4 & 40 & 50,6 & & & \\
\hline
\end{tabular}

* signifikan, nilai $p<0,05$

Analisis pada model 3 menunjukkan perubahan nilai OR pada variabel jenis kontrasepsi setelah variabel BMI dan lama pemakaian kontrasepsi dimasukkan secara bersama dalam analisis (OR 2,45; IK 95\% (0,71-8,50), $\mathrm{p}=0,16)$. Analisis menunjukkan variabel BMI menunjukkan hubungan bermakna dengan densitas tulang, sedangkan lama pemakaian kontrasepsi tidak menunjukkan hubungan yang bermakna. Model 3 memberikan kontribusi sebesar $20 \%$ terhadap kejadian densitas tulang tidak normal. Secara statistik tidak terdapat hubungan yang bermakna antara pemakaian implan dengan densitas tulang tidak normal setelah dikontrol dengan variabel BMI dan lama pemakaian kontrasepsi. Variabel yang paling berpengaruh menyebabkan kejadian densitas tulang tidak normal adalah $\mathrm{BMI}<18,5$. 
Tabel 5. Analisis multivariat hubungan antara variabel bebas (jenis kontrasepsi) dan variabel tergantung (densitas massa tulang) dikontrol dengan variabel luar (BMI dan lama pemakaian kontrasepsi)

\begin{tabular}{|c|c|c|c|}
\hline \multirow[b]{2}{*}{ Variabel } & Model 1 & Model 2 & Model 3 \\
\hline & $\begin{array}{c}\text { OR } \\
\text { IK 95\% } \\
\text { P }\end{array}$ & $\begin{array}{c}\text { OR } \\
\text { IK 95\% } \\
\text { P }\end{array}$ & $\begin{array}{c}\text { OR } \\
\text { IK 95\% } \\
\text { P }\end{array}$ \\
\hline \multicolumn{4}{|l|}{ Jenis Kontrasepsi } \\
\hline Implan & $\begin{array}{l}2,01 \\
(0,77-5,26) \\
0,16\end{array}$ & $\begin{array}{l}2,14 \\
(0,70-6,52) \\
0,18\end{array}$ & $\begin{array}{l}2,45 \\
(0,71-8,50) \\
0,16\end{array}$ \\
\hline $\begin{array}{l}\text { Non Hormonal } \\
\text { BMI }\end{array}$ & 1 & 1 & 1 \\
\hline \multirow[t]{2}{*}{$<18,5$} & & $\begin{array}{l}23,24 \\
(4,26- \\
126,86)\end{array}$ & $\begin{array}{l}17,98 \\
(3,49-112,28)\end{array}$ \\
\hline & & $<0,001 *$ & $0,001^{*}$ \\
\hline $18,5-<25$ & & $\begin{array}{l}1,44 \\
(0,36-5,85) \\
0,61\end{array}$ & $\begin{array}{l}1,18 \\
(0,32-5,54) \\
0,69\end{array}$ \\
\hline$\geq 25$ & & 1 & 1 \\
\hline \multicolumn{4}{|l|}{ Lama pemakaian } \\
\hline$\geq 5$ tahun & & & $\begin{array}{l}0,50 \\
(0,10-2,37) \\
0,38\end{array}$ \\
\hline $3-<5$ tahun & & & $\begin{array}{l}0,66 \\
(0,14-3,26) \\
0,61\end{array}$ \\
\hline$<3$ tahun & & & 1 \\
\hline $\mathrm{R}^{2}$ & 0,02 & 0,19 & 0,20 \\
\hline-2 log likelihood & 108,022 & 87,054 & 86,27 \\
\hline $\mathrm{N}$ & 110 & 110 & 110 \\
\hline
\end{tabular}

* signifikan, nilai $\mathrm{p}<0,05$ 


\section{PEMBAHASAN}

Pada penelitian ini didapatkan bahwa kejadian densitas massa tulang tidak normal pada penggunaan implan levonorgestrel tidak bermakna dengan nilai $p>0,05$.

Bahamondes et al. menyimpulkan dalam penelitian kohort prospektif yang melibatkan 110 wanita bahwa setelah 18 bulan pemakaian implan didapatkan penurunan densitas tulang midshaft ulna dengan nilai $p=0,001 .{ }^{4}$ Namun tidak didapati penurunan densitas tulang yang bermakna pada pengukuran tulang distal radius. Studi potong lintang VanderJagt et al. menunjukkan tidak ada perbedaan bermakna kejadian densitas tulang rendah pada kelompok pemakai implan dibandingkan dengan kelompok non hormonal tidak bermakna. ${ }^{7}$ Beerthuizen et al. dalam penelitian kohort prospektifnya menyatakan bahwa Implanon aman digunakan untuk wanita muda yang belum mencapai peak bone mass, didapatkan bahwa tidak ada hubungan bermakna antara densitas masa tulang dengan kontrasepsi implan dibanding dengan non hormonal. ${ }^{8}$ Demikian juga penelitian yang dilakukan oleh Di et al., pengukuran densitas tulang pada tulang belakang 2-4 dan proksimal femur tidak secara signifikan mengalami penurunan setelah 12 bulan pemakaian dibandingkan dengan baseline. ${ }^{9}$

Berbeda dengan hasil penelitian ini, Pongsatha et al. menyatakan bahwa pemakaian implan pada jangka waktu lama memiliki dampak negatif terhadap densitas tulang pada distal radius dan ulna, namun pada tulang belakang dan femur tidak didapatkan nilai densitas tulang yang tidak normal. ${ }^{6}$ Monteiro-Dantes et al. dalam penelitian kohort prospektif mendapatkan penurunan densitas tulang yang bermakna pada tulang distal radius setelah 36 bulan pemakaian kontrasepsi implan dibandingkan baseline, namun tidak didapatkan penurunan bermakna pada tulang ultra-distal radius. ${ }^{10}$

Dua golongan utama dari kontrasepsi progestinonly adalah turunan testosteron seperti levonor- gestrel dan turunan progesteron seperti medroksiprogesteron asetat (DMPA). Levonorgestrel memiliki variasi efek pada fungsi ovarium, berbeda dengan DMPA yang secara kuat menekan estrogen sehingga kadarnya seperti pada fase folikuler dalam siklus menstruasi normal. Pada studi 5 tahun pemakaian kontrasepsi levonorgestrel yang dilakukan oleh Brache et al., 38\% memiliki level fluktuasi estradiol normal, 27\% memiliki level estradiol yang rendah dan sisanya $35 \%$ memiliki level estradiol tinggi. ${ }^{11}$ Variasi efek inilah yang mungkin menyebabkan pula variasi terjadinya keadaan hipoestrogen pada pengguna kontrasepsi levonorgestrel, sehingga level estrogen pada masing-masing individu berbeda.

Pada penelitian ini didapatkan BMI underweight secara bermakna memiliki angka kejadian densitas tulang tidak normal lebih besar dibandingkan dengan $B M I$ overweight dengan $p=0,001$. Walaupun efek BMI terhadap densitas tulang masih belum jelas, namun banyak penelitian yang telah dilakukan untuk mencari hubungan antara BMI dan densitas tulang. Fawzy et al. menyebutkan bahwa BMI merupakan indikator yang baik pada wanita pasca menopause untuk pemeriksaan densitas tulang, untuk mengetahui apakah ada faktor risiko terjadinya fraktur. ${ }^{12}$ Penelitian Ong et al. menyebutkan BMI yang rendah sebanding dengan hasil densitas tulang yang rendah pula. ${ }^{13}$ Begitu pula dengan penelitian yang dilakukan oleh Asomaning et al. dan Kim et al. juga menyatakan bahwa BMI dan densitas tulang memiliki hubungan bermakna, dimana nilai BMI yang rendah merupakan prediktor densitas tulang yang rendah pula. ${ }^{14,15}$

WHO pernah mengeluarkan pernyataan bahwa levonorgestrel implan tidak memiliki efek buruk terhadap densitas tulang, dan tidak ada restriksi penggunaan metode kontrasepsi ini bagi wanita yang ingin menggunakannya. ${ }^{16}$ Hasil pernyataan tersebut sama dengan hasil penelitian ini, bahwa tidak ada hubungan bermakna antara penggunaan kontrasepsi implan dengan angka kejadian densitas massa tulang tidak normal. Densitas tulang menjadi suatu masalah 
yang dikhawatirkan terutama pada wanita, karena memasuki usia menopasuse, densitas tulang secara alami mengalami penurunan yang bermakna atau rapid bone loss. Densitas tulang merupakan salah satu faktor untuk menilai risiko terjadinya fraktur pada wanita pada usia menopause, walaupun densitas tulang bukan satu-satunya indikator penilaian.

Pada penelitian ini alat ukur densitas massa tulang peserta adalah densitometri ultrasonografi dan pengukuran dilakukan pada tulang kalkaneus. VanderJagt et al. mengadakan penelitian tentang pengaruh Norplant terhadap densitas tulang dan menggunakan densitometri ultrasonografi juga sebagai alat ukurnya. ${ }^{7}$ Maghraoui et al. menyebutkan bahwa densitometri ultrasonografi merupakan alat yang cukup nyaman, efisien, murah dan non invasif dalam menilai densitas tulang seseorang. ${ }^{17}$ Penelitian Constant et al. yang melibatkan 3493 peserta menyokong penggunaan densitometri ultrasonografi sebagai alat ukur densitas tulang epidemiologikal yang dapat mengidentifikasi risiko fraktur seperti halnya DEXA. ${ }^{18}$ Kelemahan pada alat ini yaitu pengukuran hanya bisa dilakukan pada tulang perifer seperti kalkaneus, namun tidak bisa dilakukan pada lokasi lainnya. Bagaimanapun juga DEXA merupakan alat ukur yang paling ideal dan reliable untuk menilai densitas massa tulang seseorang. WHO menyatakan bahwa DEXA merupakan gold standard dalam pengukuran densitas massa tulang dan penentuan kriteria diagnosis berdasarkan dengan hasil T-score. ${ }^{19}$

\section{KESIMPULAN DAN SARAN}

Pada penelitian ini didapatkan bahwa tidak ada perbedaan densitas massa tulang yang bermakna antara kelompok pengguna kontrasepsi implan dan kontrasepsi non hormonal. BMI secara signifikan memiliki hubungan dengan densitas tulang, dimana pada kategori BMI underweight didapatkan angka kejadian densitas tulang tidak normal lebih tinggi.
Penelitian ini menggunakan rancangan penelitian potong lintang sehingga baseline densitas massa tulang masing-masing peserta penelitian tidak diketahui. Diperlukan penelitian yang lebih lanjut dengan metode penelitian yang lebih baik daripada penelitian ini.

Alat ukur yang digunakan pada penelitian ini adalah densitometri portable ultrasound yang bukan merupakan gold standard untuk pengukuran densitas massa tulang. Dianjurkan menggunakan DEXA sebagai alat ukur densitas tulang yang lebih terpercaya.

\section{DAFTAR PUSTAKA}

1. Badan Koordinasi Keluarga Berencana Nasional. Laporan umpan balik hasil pelaksanaan subsistem pencatatan dan pelaporan pelayanan kontrasepsi. Jakarta, 2012

2. Sperrof, L. \& Fritz, M.A. Clinical Gynecologic Endocrinology and Infertility, $8^{\text {th }}$ edition. Philadelphia, 2011; Lippincott Williams \& Wilkins

3. Affandi, B., Wijayanegara, H., Permadi, W., Soedarto, W., Hasan, M., Serudji, J.R., Ngartjono, W., Nagoy, N., Prihyugiarto, T.Y., Anggraeni, M., Asih, L. Comparative study of Indoplant and Norplant in Indonesia. Research report from multi centers research in collaboration with BKKBN 2005

4. Bahamondes, L., Monteiro-Dantas, C., Espejo-Arce, X., dos Santos Fernandes, A.M., Lui-Filho, J.F., Perrotti, M. A prospective study of the forearm bone density of users of etonogestrel and levonorgestrel-releasing contraceptive implants. Human Reproduction 2006; 21: 466-70.

5. Raisz, L.G., et al. Metabolic Bone Disease. In: Larsen, P.R., Kronenberg, H.M., Melmed, S., Polonsky, K.S. Williams Textbook of Endocrinology $10^{\text {th }}$ edition. Philadelphia: Saunders, 2003; 1373-402

6. Pongsatha, S., Ekmahachai, M., Suntornlimsiri, N., Morakote, N., Chaovisitsaree, S. Bone mineral density in women using the subdermal contraceptive implant Implanon for at least 2 years. International Journal of Gynecology and Obstetrics 2010; 109: 223-225

7. VanderJagt, D.J., Sagay, A.S., Imade, G.E., Farmer, S.E., Glew, R.H. Effect of Norplant contraceptive on the bones of Nigerian women as assessed by 
quantitative ultrasound and serum markers of bone turnover. Journal of Contraception 2005; 72: 21216

8. Beerthuizen, R., van Beek, A., Massai, R., Mäkäräinen, L., Hout, J., Bennick, H.C. Bone mineral density during long-term use of the progestogen contraceptive implant Implanon compared to a non-hormonal method of contraception. Human Reproduction 2000; 15: 118-22

9. Di, X., Li, Y., Zhang, C., Jiang, J., Gu, S. Effects of levonorgestrel-releasing subdermal contraceptive implants on bone density and bone metabolism. Contraception 1999; 60: 161-6

10. Monteiro-Dantas, C., Espejo-Arce, X., Lui-Filho, J.F., Fernandes, A.M., Monteiro, I., Bahamondes, L. A three year longitudinal evaluation of the forearm bone density of users of etonogestrel and levonorgestrel releasing contraceptive implants. Reprod Health 2007; 4: 11-5

11. Brache, V., Alvarez-Sanchez, F., Faundes, A., Tejada, A.S., Cochon, L. Ovarian endocrine function through five years of continuous treatment with Norplant subdermal contraceptive implants. Contraception 1990; 41:169-77

12. Fawzy, T., Muttappallymyalil, J., Sreedharan, J., Ahmed, A., Alshamsi, S.O., Al Ali, M.S., Al Balsooshi, K.A. Association between body mass index and bone mineral density in patients referred for dualenergy x-ray absorptiometry scan in Ajman, UAE. J Osteoporos 2011:876309 doi: 10.4061/2011/ 876309

13. Ong, T., Sahota, O., Tan, W., Marshall, L. A United Kingdom perspective on the relationship between body mass index (BMI) and bone heatlh: A cross sectional analysis of data from the Nottingham Fracture Liaison Service. J Bone 2013; 28

14. Asomaning, K., Bertone-Johnson, E.R., Nasca, P.C., Hooven, F., Pekow, P.S. The association between body mass index and osteoporosis in patients referred for bone mineral density examination. J Women Health 2006; 15(9): 1028-34

15. Kim, S.J., Yang, W.G., Cho, E., Park, E.C. Relationship between weight, body mass index and bone mineral density of lumbar spine in women. Journal of Bone Metabolism 2012; 19(2): 95-102

16. Departement of Reproductive Health and research, World Health Organization, WHO statement on hormonal contraception and bone health. Contraception 2005; 73: 443-44

17. Maghraoui, A.E., Morjane, F., Mounach, A., Ghazi, M., Nouijai, A., Achemical, L., Bezza, A., Ghozlani, I. Performance of calcaneus quantitative ultrasound and dual-energy X-ray absorptiometry in discrimination of prevalent asymtomatic osteoporotic fracture in postmenopause women, Rheumatol Int 2009; 29: 551-6

18. Constant, D., Rosenberg, L., Zhang, Y., Cooper, D., Kalla, A.A., Lisa Micklesfield, L., Hoffman, M. Quantitative ultrasound in relation to risk factors for low bone mineral density in South African premenopausal women. Arch Osteoporos 2009; 4(12): $55-65$

19. World Heatlh Organization. Prevention and management of osteoporosis: Report of a WHO scientific group. WHO, Geneva, 2003 (WHO technical report series no 921) 